\title{
Morphological Computing and Cognitive Agency ${ }^{\dagger}$
}

\author{
Gordana Dodig-Crnkovic ${ }^{1, *}$ and Robert Lowe ${ }^{2}$ \\ 1 Department of Computer Science and Engineering, Chalmers University of Technology, Gothenburg 40482, \\ Sweden \\ 2 Department of Applied IT, University of Gothenburg, Gothenburg 41296, Sweden; robert.lowe@gu.se \\ * Correspondence: gordana.dodig-crnkovic@chalmers.se \\ + Presented at the IS4SI 2017 Summit DIGITALISATION FOR A SUSTAINABLE SOCIETY, Gothenburg, \\ Sweden, 12-16 June 2017.
}

Published: 7 September 2017

Morphological computing, at its core, entails that the morphology (shape + material properties) of an agent (a living organism or a machine) enables and constrains its possible (physical and social) interactions with the environment as well as its development, including its growth and reconfiguration [1]. The role of such computation in cognitive systems includes the off-loading of control onto the body and its interaction with the environment thus enabling flexible and adaptive behavior [2-7]. In a more general sense, cognitive agency instantiated by the interaction processes of morphological structures in networks of networks of cognitive agents from cells to organisms and societies is a basis of understanding of embodiment of cognition on variety of levels of (self-)organisation of physical matter from its basic physical structures via chemistry and biology with life itself as cognitive process [1].

The embodied cognition approach holds that cognition is grounded in environmental interactions in the world and is invisible in classical symbolic representation accounts of cognitive function, which is modeled on human "thinking" or "mentality". However, modern computational perspectives on cognition such as natural computation (including info-computationalism) account for embodiment whereby cognitive processes are considered to emerge from interactions in the world cf. [8-12].

In this symposium we have brought together perspectives on morphological computation and embodied cognition and encouraged open and constructive debate on the perceived differences in the various perspectives on constructivist and computationalist accounts of cognition, and specifically embodied cognition.

Lorenzo Magnani based his talk on the notion of "mimetic minds" explaining eco-cognitive computationalism generating morphology-based enhancement of "mimetic bodies". Tom Ziemke addressed the role of morphology in intentional agency and social interaction. The topic of human robot interactions was analyzed in Jordi Vallverdu's talk on the morphologies of affect. Ron Chrisley studied the roles for morphology in computation understood as information transformation performed by the morphological aspects of a system (the shape, geometry, placement and compliance properties). Marcin Milkowski explored in his talk the question if morphological computation special, suggesting the negative answer. This view is in agreement with Marcin Schroeder's talk addressing computing with nature, as well as the view of morphological computation as natural computation [1].

\section{References}

1. Dodig-Crnkovic, G. The Info-computational Nature of Morphological Computing. In Theory and Philosophy of Artificial Intelligence; Müller, V.C., Ed.; Springer: Berlin, Germany, 2012; pp. 59-68. 
2. Hauser, H.; Füchslin, R.M.; Nakajima, K. Morphological Computation-The Physical Body as Computational Resource. In Opinions and Outlooks on Morphological Computation; 2014, Chapter 20, ISBN 978-3-033-04515-6. Available online: http://tinyurl.com/pjvey43 (accessed on 6 June 2017).

3. Pfeifer, R.; Bongard, J. How the Body Shapes the Way We Think: A New View of Intelligence; MIT Press: London, UK, 2006.

4. Kohei, N.; Hauser, H.; Li, T.; Pfeifer, R. Information processing via physical soft body. Sci. Rep. 2015, 5, 10487, doi:10.1038/srep10487. Available online: https://www.nature.com/articles/srep10487 (accessed on 6 June 2017).

5. Hauser, H.; Ijspeert, A.; Füchslin, R.; Pfeifer, R.; Maass, W. Towards a theoretical foundation for morphological computation with compliant bodies. Biol. Cybern. 2011, 105, 355-370. Available online: http://www.springerlink.com/content/j236312507300638/ (accessed on 6 June 2017).

6. McEvoy, M.A.; Correll, N. Materials that couple sensing, actuation, computation, and communication. Science 2015, 6228, 1261689.

7. Wilson, M. Six views of embodied cognition. Psychon. Bull. Rev. 2002, 9, 625-636. Available online: http://www.ncbi.nlm.nih.gov/pubmed/12613670 (accessed on 6 June 2017).

8. Scheutz, M. Computationalism: The next generation. In Computationalism: New Directions; MIT Press: Cambridge, MA, USA, 2002; pp. 517-524.

9. Chrisley, R. Synthetic Phenomenology. Int. J. Mach. Conscious. 2009, 1, 53-70.

10. Dodig-Crnkovic, G.; Müller, V. A Dialogue Concerning Two World Systems: Info-Computational vs. Mechanistic. Book chapter. In Information and Computation; Dodig-Crnkovic, G., Burgin, M., Eds.; Series in Information Studies; World Scientific Publishing Co.: Singapore, Singapore. 2011; pp. 149-184. Available online: http://arxiv.org/abs/0910.5001 2009 (accessed on 6 June 2017).

11. Milkowski, M. Explaining the Computational Mind; MIT Press: Cambridge, MA, USA, 2013.

12. Schroeder, M.J.; Vallverdú, J. Situated Phenomenology and Biological Systems: Eastern and Western Synthesis. Prog. Biophys. Mol. Biol. 2015, 119, 530-537, doi:10.1016/j.pbiomolbio.2015.06.019. 